\title{
Hukuman Terhadap Tindak Pidana Kekerasan dalam Rumah Tangga Menurut Hukum Islam
}

\author{
Risdianto \\ Universitas Muhammadiyah Jakarta \\ Email: risdianto@umj.ac.id
}

\begin{abstract}
Domestic violence is a serious concern of all parties, thus giving birth to Law Number 23 of 2004 concerning the elimination of domestic violence. According to Islam, domestic violence is different from other criminal acts, such as murder, injuring qisahah, theft by cutting off hands, adultery with caning or stoning. The basis for criminal sanctions for domestic violence is not explained in the text (alQur'an and Hadith), so the punishment is expressly absent. This study uses a qualitative method that aims to enrich the scientific treasures of Islamic law and input for parties related to legal matters. The research found that domestic violence criminal sanctions are ta'zir punishment determined by the ruler (government), because it is not explained in the al-Qur'an or Hadith, so that its existence is left to the ruler's decision. This punishment (Jarimah) ta'zir is different from other punishments such as murder, adultery, theft and others whose explanation is contained in Islamic law.
\end{abstract}

Keywords: Criminal Sanctions, Domestic Violence, Ta'zir.

\begin{abstract}
Abstrak
Kekerasan dalam rumah tangga menjadi perhatian yang serius dari semua pibak sehingga melabirkan Undang-undang Nomor 23 tahun 2004 tentang penghapusan kekerasan dalam rumah tangga. Menurut Islam, kekerasan dalam rumah tangga berbeda dengan tindak pidana lainnya, seperti pembunuban, pelukaan bukuman qisabah, pencurian dengan potong tangan, perzinaban dengan bukuman cambuk atapun rajam. Sanksi pidana kekerasaan dalam rumah tangga tidak dijelaskan dasarnya dalam nash (al-Qur'an dan Hadist), sehingga bukumannya secara tegas tidak ada. Penelitian ini menggunakan metode kualitatif yang bertujuan memperkaya khazanah keilmuan bukum Islam dan masukan bagi pibak terkait urusan bukum. Hasil penelitian ditemukan bahwa sanksi pidana kekerasan dalam rumah tangga adalah hukuman ta'zir yang ditetapkan penguasa (pemerintab), karena tidak dijelaskan dalam al-Qur'an ataupun Hadist, sehingga keberadaanya disserabkan kepada keputusan penguasa. Hukuman (jarimah) ta'zir ini berbeda dengan bukuman lainnya seperti pembunuban, perzinahan, pencurian dan lainnya yang penjelasannya terdapat dalam bukum Islam.
\end{abstract}

Kata Kunci: Sanksi Pidana, Kekerasan Dalam Rumah Tangga, Ta’żir.

\section{A. Pendahuluan}

Tindak kekerasan di dalam rumah tangga pada umumnya melibatkan pelaku dan korban diantara anggota keluarga di dalam rumah tangga, sedangkan bentuk tindak kekerasan bisa berupa kekerasan fisik dan kekerasan verbal (ancaman 
kekerasan). Pelaku dan korban tindak kekerasan didalam rumah tangga bisa menimpa siapa saja, tidak dibatasi oleh strata, status sosial, tingkat pendidikan, dan suku bangsa. ${ }^{1}$

Dalam kitab Undang-undang Hukum Pidana (KUHP) telah dirumuskan pasal-pasal tentang tindak pidana penganiayaan, namun belum dianggap mengakomodir perbuatan pidana yang berkaitan dengan kekerasan dalam rumah tangga. Menurut persektif hukum pidana Islam, tindak pidana kekerasan dalam rumah tangga, terutama kekerasan fisik terhadap istri dalam UU PKDRT merupakan bagian dari perbuatan jarimah yaitu tidak pidana atas selain jiwa. Kekerasan dalam rumah termasuk Jarimah yang dikelompokkan kejahatan selain jiwa (fisik), sehingga dimasukkan tindak pidana.

Data yang diperolah Komnas Perempuan mencatat jumlah kasus KDRT atau RP di tahun 2014 dalam Catatan Tahunan 2015 Komnas Perempuan, sebagai berikut:

1) Sebanyak 8.626 kasus di ranah personal, 59\% atau 5.102 kasus berupa kekerasan terhadap istri, 21\% atau 1.748 kasus kekerasan dalam pacaran, 10\% atau 843 kasus kekerasan terhadap anak perempuan, 9\% atau 750 kasus kekerasan dalam relasi personal lain, $1 \%$ atau 63 kasus kekerasan dari mantan pacar, 0,7\% atau 53 kasus kekerasan dari mantan suami, dan 0,4\% atau 31 kasus kekerasan terhadap pekerja rumah tangga. 2) Kasus kekerasan fisik masih menempati urutan tertinggi pada jenis tindak kekerasan dalam ranah personal di tahun 2014, yaitu mencapai 3.410 (40\%), diikuti posisi kedua kekerasan psikis sebesar 2.444 (28\%), kekerasan seksual 2.274 kasus (26\%) dan kekerasan ekonomi 496 kasus (6\%). Urutan di atas sama dengan data tahun 2013. 3) Mayoritas rentang usia perempuan korban di ranah personal adalah 25-40 tahun, menyusul setelahnya di usia 13-18 tahun, kemudian di usia 19-24 tahun. Ini berarti bahwa kekerasan tertinggi terjadi pada usia nikah (25-40 tahun). ${ }^{2}$

Pada dasawarsa akhir-akhir ini masalah kekerasan dalam rumah tangga sering terjadi di tengah-tengah kehidupan masyarakat, baik di kalangan masyarakat yang berpendidikan sekolah Dasar maupun yang berpendidikan sarjana, sehingga sudah

${ }^{1}$ Didi Sukardi, Kajian Kekerasan Rumah tangga Dalam Perspektif Hukum Islam Dan Hukum Positif, Mabkamah Vol.9 No. 1 Januari 2015,.https://www.syekhnurjati.ac.id (dikases pada tanggal 20 Januari 2021).

${ }^{2}$ Nur Rofiah, "Kekerasan Dalam Rumah Tangga dalam Perspektif Islam", Wawasan: Jurnal Ilmiah Agama dan Sosial Budaya 2,1 (Juni 2017): 31-44. 
menjadi permasalahan yang sudah sering terjadi di masyarakat, bahkan tidak melihat latar belakang pendidikannya. Akibat dari tindakan kekerasan dalam rumah tangga biasanya yang menjadi korban adalah kaum perempuan dan anakanak dan dilakukan oleh suami atau ayah sebagai pelindung keluarga.

Kekerasan yang tejadi dalam rumah tangga biasanya disebabkan oleh hal-hal sepele dan berakhir menjadi pertengkaran hebat, serta menyebabkan terjadinya kekerasan, baik itu kekerasan fisik maupun kekerasan psikis ataupun yang lainnya. Kekerasan emosional berbentuk canda atau perlakuan yang merendahkan martabat seseorang atau pelecehan seksual merupakan kekerasan emosional yang tidak dapat dilihat, namun memiliki dampak yang lebih besar dari bentuk kekerasan lainnya, namun demikian semua kekerasan memiliki andil dalam menyebarkan ketakutan dan penderitaan yang dirasakan perempuan dalam masyarakat.

Menurut WHO kekerasan ada beberapa jenis yang meliputi: kekerasan fisik (tindakan yang menyebabkan rasa sakit atau potensi menyebabkan sakit), kekerasan seksual (kegiatan seksual yang tidak dipahaminya seperti dirayu, dicolek, dipeluk secara nafsu diperkosa secara paksa), kekerasan pengabaian dan penelantaran (ketidakpedulian orangtua, atau orang yang bertanggung jawab atas anak), kekerasan emosional (dapat menyebabkan terhambatnya perkembangan emosional anak), kekerasan ekonomi (penggunaan tenaga anak untuk bekerja dan kegiatan lainnya). ${ }^{3}$ Sedangkan dalam Undang-Undang nomor 23 tahun 2004 ada berapa macam kekeraasan yaitu kekerasan fisik, kekerasan psikis, kekerasan seksual, kekerasan penelantaran rumah tangga. ${ }^{4}$

Menurut Levi yang dimaksud dengan kekerasan adalah merupakan konsep yang makna dan isinya sangat tergantung kepada masyarakat sendiri. ${ }^{5}$ Kemudian dalam pasal 2 Deklarasi PBB tentang penghapusan kekerasan terhadap perempuan dijelaskan bahwa:

\footnotetext{
${ }^{3}$ Murpiaty, Makalah Perlindungan Terhadap Korban Akibat Kekerasan Terhadap Perempuan Dalam Rumah Tangga.

${ }_{4}$ Undang-Undang RI Nomor 23 Tahun 2004 Tantang kekerasan Dalam Rumah Tangga, (Bandung, Citra Umbara, 2007), h. 4.

${ }^{5}$ Fathul Djanah DKK, Kekerasan Teradap Istri, (Yogyakarta: Penerbit LKIS, 2003), h. 11.
} 
"Kekerasan terhadap perempuan adala setiap perbuatan berdasarkan perbedaan kelamin yang berakibat atau mungkin berkaibat kesengsaraan dan penderitaan perempuan secara fisik, seksual atau psikologis, termasuk ancaman tindakan tertentu, pemaksaan atau perampasan kemerdekaan secara sewenang-wenang, baik yang terjadi di depan umum atau dalam keidupan pribadi."6

Dalam azazs-azas hukum pidana Islam, tindak pidana atau jarimah dapat ditinjau dalam berbagai aspek, sehingga tindak pidana atau jarimah dapat diklasifikasikan dalam berbagai macam aspek yang meliputi; hukuman, niat, cara, korban, dan tabiat. Para ulama mengelompokkan jarimah dengan melihat pada hak siapa yang terlanggar dalam kejahatan itu. ${ }^{7}$

Berbicara mengenai kekerasan dalam rumah tangga dapat dijelaskan bawa kekerasan dalam rumah tangga adalah setiap perbuatan terhadap seseorang terutama perempuan, yang berakibat timbulnya kesengsaraan atau penderitaan secara fisik, seksual, psikologis, dan/atau penelantaran rumah tangga termasuk ancaman untuk melakukan perbuatan, pemaksaan, atau perampasan kemerdekaan secara melawan hukum dalam lingkup rumah tangga. ${ }^{8}$

Sebenarnya siapapun tidak pernah menginginkan adanya perselisihan dengan orang lain, dan tidak selayaknya melarikan diri ketika mempunyai masalah dan perselisihan dengan orang lain, sekiranya masih ada cara yang lebih aik untuk meyelesaikannya. Dengan demikian dalam hidup berkeluarga, tidak ada satu suami atau istri yang dengan sengaja membuat perselisihan dengan pasangannya. Bagaimanapun juga jika sebuah keluarga dibangun di atas fondasi cinta, kasih sayang dan saling membutuhkan, tidak akan ada yang menginginkan berpisah dari pasangannya.

Terjadinya perselisihan, pertikaian dan perbedaan pendapat dalam hidup berumah tangga adalah suatu yang tidak pernah diharapkan. Setiap manusia tidak dilahirkan dalam kondisi yang sama persis tenpa perbedaan. Bahkan anak

\footnotetext{
${ }^{6}$ Moerti Hadiati Soeroso, Kekerasan Dalam Rumah Tangga, (Jakarta: Sinar Grafika, 2010), h. 60.

7 Alfan Maulidin Ichwanto, "Tindak Pidana Penganiayaan dalam Hukum Pidana Islam", AlQanun, Vol. 20, No.1, Juni 2017

8 Agustinus Edy Kristianto, Panduan Bantuan Hukum Di Indonesia, (Jakarta: Yayasan Obor Indonesia, 2008), h. 116.
} 
kembarpun ada perbedaan, perbedaan itu sendiri adalah sunnatullah yang tak terelakkan, sehingga wajar apabila suami istri menemukan riak-riak kecil dalam romantika batera rumah tangganya.

Perbedaan dan perselisihan bukanlah aib yang harus dibuang jauh-jauh dan dihindari, selama perbedaan tersebut bukan masalah aqidah dan masalah-masalah agama yang fundamental. Apabila suami istri dapat mengatasi segala permasalahan dan perbedaan disikapi dengan emosi maka akan terjadi kekerasan dalam rumah tangga bahkan mengakibatkan perceraian.

Oleh karena itu sebelum seorang lelaki dan perempuan memutuskan membina rumah tangga, sebaiknya dalam hal memilih pasangan hidupnya harus terlebih dahulu mengenal dan memahami calon pasangannya. Setelah yakin mengenal bisa dilanjutkan pada tahap yang lebih dalam yaitu meminangnya sekaligus menikahinya. Begitu pentingnya seorang suami mengenal calon pasangannya sebelum akad nikah, sehingga apabila pernikahan telah terlaksana tidak menimbulkan perasaan menyesal, dengan adanya pengenalan awal diharapkan adanya rasa saling memahami. Saling memahami dan saling percaya adalah kunci dalam membina keluarga sakinah.

Perkawinan adalah terikatnya suatu hubungan antara seorang wanita dengan laki-laki dalam suatu hubungan yang resmi dalam lembaga perkawinan. Pernikahan juga menyatukan dua belah keluarga. Dalam al-Qur'an surat ar-Rum ayat 21 dinyatakan sebagai berikut yang artinya: Dan di antara tanda-tanda kekuasaan-Nya ialah Dia menciptakan untukmu isteri-isteri dari jenismu sendiri, supaya kamu cenderung dan merasa tenteram kepadanya, dan dijadikan-Nya diantaramu rasa kasih dan sayang. Sesungguhnya pada yang demikian itu benarbenar terdapat tanda-tanda bagi kaum yang berfikir. ${ }^{9}$

Perempuan dalam naungan Islam tidak dinilai sebagaimana menurut kalangan lain, sebagai najis yang harus dijauhi. Tetapi Islam mengangkat perempuan hingga ke puncak kemuliaan, dan menilai pernikahan sebagai nikmat Allah Swt atas para hamba-Nya. Oleh karenanya, setiap hamba berkewajiban untuk mensyukuri

\footnotetext{
${ }^{9}$ Departemen Agama RI, al-Qur'an dan Terjemahnya, (Semarang: Toha Putra, 1999), h. 644.
} 
nikmat-Nya dan tidak mengingkarinya. Salah satu rasa syukur terhadap nikmat ini masing-masing dari mereka mencari pasangan yang memelihara agama dan hakhaknya serta menjaganya, yaitu dengan mengikuti perintah-perintah Nabi, baik dalam memilih istri maupun dalam memilih suami.

Perkawinan menurut Islam adalah suatu perjanjian dan ikatan lahir batin antara seorang laki-laki dengan seorang perempuan yang dimaksudkan untuk bersama membentuk satu rumah tangga dan untuk berketurunan, serta harus dilangsungkan untuk memnuhi rukun dan syarat-syarat menurut Islam dan hukum negara. Pengertian perkawinan yang tersebut di atas mengandung akibat hukum, yaitu adanya kewajiban yang harus dilaksanakan baik bagi pihak laki-laki maupun perempuan serta adanya hak yang dimiliki oleh keduanya dalam menjalankan roda kehidupan berumah tangga.

Perkawinan juga merupakan suatu peristiwa hukum yang mendapat tempat di dalam tata hukum dan perkawinan itu harus dilakukan terang-terangan dan jelas. Dengan kata lain perkawinan atau pernikahan tidak dilakukan di bawah tangan, karena bila hal ini dilakukan maka jika terjadi perceraian atau kekerasan dalam rumah tangga, secara hukum tata negara piak perempuan akan mengalami kerugian untuk menuntut pihak laki-laki yang telah melakukan kekerasan disebaban pernikahan mereka tidak tercatat secara resmi pada lembaga yang ditunjuk oleh negara. Hal ini berguna untuk mencatat pernikahan yang terjadi dalam wilayah hukum negara Indonesia.

Dengan disahkannya Rancangan Undang-Undang perkawinan di Indonesia nomor 1 taun 1974 dengan nama Undang-Undang Republik Indonesia nomor 1 tahun 1974 tentang perkawinan. Berlakunya Undang-Undang tersebut maka segala peraturan yang ada sejauh yang tela diatur dalam Undang-Undang ini dinyatakan tidak berlaku lagi, sebagaimana disebutkan dalam pasal 66 berikut ini:

"Untuk perkawinan dan segala sesuatu yang berubungan dengan perkawinan berdasarkan undang-undang ini maka dengan berlakunya undang-undang, ketentuan-ketentuan yang diatur dalam hukum perdata (Burgelijk Wetboekj), ordonansi perkawinan Indonesia Kristen (Huwelijks ordonantie Christen Indonesia S. 1933 nomor 74), peraturan perkawinan campuran (Regeling of Degemende Huwej 
Ken S. 1898 nomor 158) dan peraturan-peraturan lain yang mengatur tentang perkawinan sejauh daitur dalam undang-unang ini dinyatakan tidak berlaku."'10

Negara Indonesia sangat konsen dalam mengapresiasi hak antara suami dan istri sehingga antara keduanya tidak boleh melakukan kejahatan pidana seperti melakukan kekerasan dalam rumah tangga. Harapan dengan realitas belum maksimal, sehingga walaupun sudah diberlakukannya Undang-Undang nomor 23 tahun 2004 ternyata masih banyak terjadi kekerasan dalam rumah tangga dalam berbagai aspek dan sisi. Hal inilah yang menjadi latar belakang dan perhatian peneliti untuk mengetahuinya, sebagaimana yang pernah dijadikan tema dalam penelitian ini.

Begitu banyaknya kasus kekerasan dalam rumah tangga sesuai dengan data di atas, maka penting sekali penelitian ini dispesipkkan ke dalam hukum pidana Islam. Walaupun ada juga penelitian yang membahasnya, paling tidak dalam peneltian ini bisa diambil satu pemahaman ternyata agama Islam juga membahas sanksi pidana kekerasan dalam rumah tangga.

\section{B. Metode Penelitian}

Penelitian ini menggunakan metode penelitian kualitatif, menurut meleong penelitian kualitatif adalah penelitian yang bertujuan memahamkan tentang fenomena yang terjadi pada subjek penelitian misalnya, perilaku, persepsi dan motivasi. ${ }^{11}$ Sumber data penelitian yaitu primer dan sekunder, Data primer merupakan data yang diperoleh peneliti dari sumber pokok yaitu menurut hukum Islam dan Undang-undang nomor 23 tahun 2004 sebagai bahan tambahan., data sekunder adalah data yang diperoleh dari sumber kedua.

\section{Hasil dan Pembahasan}

\section{Penyebab Maraknya Kekerasan dalam Rumah Tangga}

Berdasarkan Undang-Undang Republik Indonesia nomor 23 tahun 2004 tentang penghapusan kekerasan dalam rumah tangga pada bab I pasal 1 dijelaskan

10 Undang-undang Nomor 1 Tahun 1974 Tentang Perkawinan dan Peraturan Pemerintah nomor 9 Tahun 1975 serta Kompilasi Hukum Islam di Indonesia, (Jakarta: Departemen Agama R.I) h. 46.

${ }^{11}$ Muhammad Nazir, Metode Penelitian, (Jakarta: Ghalia Indonesia, 2005). 
yaitu: "Kekerasan dalam rumah tangga adalah setiap perbuatan terhadap seseorang terutama perempuan, yang berakibat timbulnya kesengsaraan atau penderitaan secara fisik, seksual, psikologis, dan/atau penelantaran rumah tangga termasuk ancaman untuk melakukan perbuatan, pemaksaan, atau perampasan kemerdekaan secara melawan hukum dalam lingkup rumah tangga."12

Islam telah mengatur bahwa pernikahan adalah pekerjaan mulia yang sangat dianjurkan untuk dilaksanakan oleh setiap muslim, sekiranya telah memenuhi syarat untuk menikah. Perkawinan akan menimbulkan hak dan kewajiban timbal balik antara suami dan istri. Namun demikian perkawinan bukanlah semata-mata perhitungan hak dan kewajiban, melainkan berisi kasih sayang, saling memberi dan menerima, juga untuk saling melindungi dan saling mengisi guna mencapai kedamaian, ketenteraman dan kebahagiaan.

Secara fitrahnya setiap manusia pasti merindukan kasih sayang, sehingga sangat naif melakukan kejahatan di antara sesamanya. Tapi pada kenyataannya dunia hari ini sangat jauh dari suasana berkasih sayang. Bahkan kasih sayang yang hakiki sudah hilang dari hati manusia. Hal ini dapat dilihat dengan banyaknya tindak pidana kekerasan yang terjadi, baik dalam rumah tangga maupun dalam kehidupan bermasyarakat dan bahkan dalam kehidupan bernegara, sehingga terjadinya krisis dan pergolakan.

Terjadinya kekerasan dalam rumah tangga dapat disebabkan adanya berbagai faktor. Maksudnya dapat dipengaruhi oleh faktor dari luar atau lingkungan, tetapi dapat juga dipicu karena adanya faktor dari dalam diri pelaku sendiri. Hal ini dapat diperoleh dari kasus-kasus yang pernah terjadi dan ditangani oleh lemaga bantuan hukum. Menurut LKBHUWK, sebuah lembaga bantuan hukum untuk perempuan dan keluarga, penyebab terjadinya kekerasan dalam rumah tangga dapat digolongkan menjadi 2 (dua) faktor, yaitu faktor internal dan faktor eksternal. ${ }^{13}$

\section{h. 2 .}

12 Undang-Undang RI Nomor 23 Tahun 2004 Tantang kekerasan Dalam Rumah Tangga, 2007,

${ }^{13}$ Moerti Hadiati Soeroso, Kekerasan ..., h. 76. 
Faktor internal menyangkut kepribadian dari pelaku kekerasan yang menyebabkan ia mudah sekali melakukan tindak pidana kekerasan bila menghadapi situasi yang menimbulkan kemarahan atau frustasi. Kepribadian yang agresif biasanya dibentuk melalui interkasi dalam keluarga atau dengan lingkungan sosial di masa kanak-kanak. Faktor eksternal adalah faktor-faktor di luar diri si pelaku kekerasan. Mereka yang tidak tergolong memiliki tingkah laku agresif dapat melakukan tindak kekerasan bila berhadapan dengan situasi yang menimbulkan frustasi misalnya kesulitan ekonomi yang berkepanjangan, peyelewengan suami atau istri, keterlibatan anak dalam kenakalan remaja atau penyalahgunaan obat terlarang dan sebagainya. ${ }^{14}$

Dengan demikian banyak hal yang dapat meyebabkan terjadinya kekerasan dalam rumah tangga, sehingga faktor yang terbesar adalah dari sisi luar (eksternal) pelaku kekerasan tersebut, jika diandingkan faktor internal. Dalam penelitian ini deikemukakan sacara ringkas mengenai faktor-faktor terjadinya kekerasan dalam rumah tangga yaitu seagai berikut:

Pertama, faktor keuangan. Uang seringkali dapat menjadi pemicu timbulnya perselisihan di antara suami dan istri. Gaji yang tidak cukup untuk memenuhi kebutuhan rumah tangga setiap bulannya, seringkali menimbulkan pertengkaran, apalagi kalau pencari nafkah yang utama adalah suami. Dapat juga pertengkaran timbul ketika suami kehilangan pekerjaan. Ditambah lagi adanya tuntutan biaya hidup yang tinggi, memicu pertengkaran yang seringkali berakibat terjadinya tindak kekerasan. Kedua, faktor anak. Salah satu terjadinya perselisihan antara suami dan istri adalah masalah anak. Perselisihan dapat semakin meruncing kalau terdapat peredaan pola pendidikan terhadap anak antara suami dan istri. Hal ini dapat berlaku baik terhadap anak kandung maupun terhadap anak tiri atau anak asuh. ${ }^{15}$

Ketiga, faktor salah paham. Suami dan istri ibarat dua buah kutub berbeda. Oleh karena itu usaha peyesuaian diri serta saling menghormati pendapat masing-

\footnotetext{
14 Moerti Hadiati Soeroso, Kekerasan ..., h. 76.

15 Moerti Hadiati Soeroso, Kekerasan ..., h. 77-80.
} 
masing pihak, perlu dipelihara. Karena kalau tidak akan timbul kesalahpahaman. Kondisi ini sering muncul oleh hal-hal sepele, namun kalau dibiarkan terus tidak akan diperoleh titik temu. Kesalahpahaman yang tidak segera dicarikan jalan keluarnya, akan menimbulkan pertengkaran dan dapat pula memicu kekerasan. Keempat, faktor masa lalu. Seharusnya sebelum melangsungkan pernikahan antara calon suami dan istri harus terbuka, masing-masing menceritakan atau memberitahukan masa lalunya. Keterbukaan ini merupakan upaya untuk mencegah salah satu pihak mengetahui riwayat masa lalu pasangan dari orang lain. Pada kenyataannya cerita yang diperoleh dari pihak ketiga sudah tidak realistis. Pertengkaran yang dipicu karena adanya cerita masa lalu masing-masing pihak berpotensi mendorong terjadinya perselisihan dan kekerasan. ${ }^{16}$

Kelima, orang tua. Orang tua dari pihak suami maupun istri dapat menjadi pemicu pertengkaran dan menyebabkan keretakan hubungan di antara suami dan istri. Orang tua yang selalu ikut campur rumah tangga anaknya, misalnya meliputi masalah keuangan, pendidikan anak atau pekerjaan, seringkali memicu pertengkaran yang berakhir dengan kekerasan apalagi hal ini bisa juga dipicu karena adanya perbedaan sikap terhadap masing-masing orang tua. Keenam, cemburu. Kecemburuan dapat juga merupakan salah satu timbulnya kesalahpahaman, perselisihan bahkan kekerasan. Pada tahun 1992 di Jakarta seorang suami tega membunuh dan melakukan mutilasi terhadap tubuh istrinya, karena istri mengetahui penyelewengan yang dilakukan oleh suami. Kasus lain terjadi tahun 2009 seorang suami melakukan tindak kekerasan terhadap istrinya, karena istri cemburu. Masih banyak lagi kasus-kasus kecemburuan yang dapat memicu terjadinya tindak kekerasan yang terjadi dalam rumah tangga. ${ }^{17}$

Ketujuh, suami mau menang sendiri. Dalam penelitian ini diperoleh gambaran bahwa masih terdapat suami yang merasa "lebih" dalam segala hal dibandingkan dengan istri. Oleh karena itu, suami menginginkan segala kehendaknya menjadi semacam "undang-undang", di mana semua orang yang tinggal dalam rumah

\footnotetext{
16 Moerti Hadiati Soeroso, Kekerasan ..., h. 77-80.

17 Moerti Hadiati Soeroso, Kekerasan ..., h. 77-80.
} 
harus tunduk kepadanya. Dengan demikian kalau ada perlawanan dari istri atau penghuni rumah yang lain, maka akan timbul pertengkaran yang diikuti dengan timbulnya kekerasan. Kedelapan, saudara. Dalam kehidupan rumah tangga, banyak dijumpai orang yang hidup bersama, seperti saudara baik dari pihak suami ataupun istrinya. Permasalahan yang muncul dalam keluarga terkadang pihak saudara tersebut turut campur, bahkan dapat mengalibatkan kekisruhan karena bukan mencari jalan keluar, malah sebaliknya menambahi masalah yang sudah ada. Hal ini tentunya dapat mengakibatkan pertengakaran sekaligus mengakibatkan kekerasan dalam rumah tangga disebabkan karena keberadaan saudara yang turut campur memperuncing masalah. Dengan demikian saudara dapat menjadi faktor penyebabnya terjadi kekerasan dalam rumah tangga. ${ }^{18}$

Kesembilan, tidak memasak. Salah satu pandangan suami adalah istri harus terus melayani suaminya, sehingga istri harus terus fokus meyelesaikan permasalahan rumah tangga, seperti istri diaruskan terrus memasak, sehingga istri di tempatkan di ranah domestik. Hal ini dapat mengakibatkan sekaligus menghambat aktifitas sitri, pdahal tidak seharusnya suami mempunyai cara fikir tersebut, oleh karena itu ketika istri tidak masak di rumah maka dapat mengakibatkan pertengkaran, sekaligus mengakibatkan terjadinya kekerasan dalam rumah tangga. Dengan demikian cara pandang suami yang menganggap istri harys di tempatkan di wilayah domestik seperti memasak dan lainnya, maka dapat mengakibatkan kekerasan rumah tangga.

Kesepuluh, sopan santun. Sopan santun dalam rumah tangga arus dijunjung tinggi oleh suami atau istri dan lainnya, sehingga dapat menjadikan hubungan yang harmonis. Tapi sebaliknya, jika pihak suami atau istri masih terbawa kebiasaan sebelum menikah harus dihilangkan. Antara suami dan istri harus saling menghormati dan saling penuh pengertian. Kalau hal ini diabaikan akibatnya dapat memicu kesalahpahaman yang memicu pertengkaran dan kekerasan secara psikis. Ada kemungkinan juga berakhir dengan kekerasan fisik. ${ }^{19}$

\footnotetext{
18 Moerti Hadiati Soeroso, Kekerasan ..., h. 77-80.

19 Moerti Hadiati Soeroso, Kekerasan ..., h. 77-80.
} 
Semua faktor di atas dapat saja terjadi dalam lingkup rumah tangga, sehingga tidak menutup kemungkinan terjadinya kekerasan dalam rumah tangga. Oleh karena itu, kesemuanya dapat dihilangkan jika suami istri memahami kedudukannya masing-masing. Dengan demikian, sikap yang bijak dan taat harus ditanamkan dalam kehidupan rumah tangga. Kesemua faktor di atas di antara penyebab terjadinya kekerasan dalam rumah tangga. Sebagian besar yang menjadi korban KDRT tersebut adalah pihak isteri. Kehidupan rumah tangga tidak terlepas dari hiruk-pikuk perbedaan pemikiran atau pendapat antara suami isteri, sehingga terkadang berakhir kepada munculnya tindakan kekerasan dalam rumah tangga.

\section{Sanksi Kekerasan dalam Rumah Tangga menurut Hukum Pidana Islam}

Tinjauan Hukum Pidana Islam terhadap sanksi bagi pelaku kekerasan dalam rumah tangga menurut UU PKDRT No. 23 tahun 2004 Pasal 46, 47, dan 48, jika dihubungkan dengan kasus kekerasan dengan unsur pemaksaan dalam hubungan seksual suami istri, dapat dikategorikan jarimah ta' żir yang sanskinya diserahkan kepada ulil amri, kemudian bagi pelaku yang melakukam perbuatan zina, hukumannya 100 kali jilid dan diasingkan selama satu tahun apabila pezinanya belum menikah. apabila pelakunya sudah berkularga, maka hukumannya dirajam sampai mati, kemudian bagi orang yang memaksa orang lain untuk melakukan zina untuk tujuan komersial atau untuk tujuan yang lainnya, maka sanksi hukumannya ta' zir. $^{20}$

Penjelesan di atas memberikan pemahaman bahwa pelaku tindak pidana kekerasan dalam rumah tangga dikenakan hukuman ta'zir menurut hukum Islam. Ta'zir menjadi hukuman yang ditetapkan oleh pemerintah ataupun imam serhingga keberadaanya tidak dijelaskan secara jelas dalam hukum Islam. Hal ini tentunya berbeda dengan tindak pidana yang ditetapkan dalam syariat seperti perzinahan, pencurian, pembunuhan dan lainnya. Pemertintah diberikan wewenang untuk menetapkan sanksi pidana terhadap pelaku kekerasan dalam rumah tangga.

20 Rahmat Fauzi, Tinjanan bukum Pidana Islam Terhadap kekerasan seksual dalam rumah tangga menurut UU No. 23 tahun 2004 tentang penghapusan kekerasan dalam rumah tangga, http://digilib.uinsgd.ac.id/2295/, (diakses pada 27 Januari 2021). 
Sanksi pidana yang diterapkan pada tindakan kekerasan dalam rumah tangga meliputi penjara atau denda sebagaimana juga sesuai dengan fungsi utama penerapan hukuman dalam Islam yaitu efek jera dan ta'dib (pembelajaran). Hanya saja, dalam penerapannya ada yang bertentangan dengan tujuan hukuman itu sendiri. sebagai contoh, suami yang melakukan kekerasan dalam rumah tangga yang miskin, jika suami harus dipidana atau didenda dengan putusan hakim, maka tentu akan menghilangkan sumber nafkah keluarga dan memperparah ekonomi keluarga. Begitu juga dengan sanksi denda yang harus diserahkan ke negara. ${ }^{21}$

Padahal dalam ketentuan hukum Islam, semua sanksi harus bertujuan untuk merealisasikan kemaslahatan meliputi pemeliharaan terhadap agama, jiwa, akal, keturunan dan harta. Maka sanksi pidana baru bisa diterapkan jika nyata-nyata tindakan seorang dalam keluarga sudah membahayakan dengan melihat prilakunya yang berulang, dalam hal ini untuk memeliharan jiwa anggota keluarga lainnya. Artinya, jika perbuatan kekerasan tersebut dilakukan sekali karena khilaf, masih ada peluang dimaafkan jika yang bersangkutan mengakui. Selain itu, sanksi denda yang diterapkan seharusnya diserahkan kepada pihak korban kekerasn yang dirugikan dan bukan kepada negara yang dalam hal ini bertindak sebagai hakam. ${ }^{22}$

Penjelasan di atas menyatakan sanksi hukuman pelaku tindak kekerasan dalam ruman menurut hukum Islam adalah ta'dib (pembelajaran). Penjelasan tersebut menawarkan jika terjadi KDRT baru sekali maka sangat dianjurkan untuk memaafkan sehingga tidak dijatuhi sanksi pidana. Hal ini memberikan kesan, diasarankan kepada korban KDRT lebih mengedepankan sikap memaafkan jika pertama kali terjadi. Dengan demikian, tetap secara konsep sanksi hukuman terhadap kekerasan dalam rumah tangga adalah ta'zir (ta'dib) yang kewenagnnya diserahkan ke penguasa.

Penelantaran suami dalam Pasal 9 Undang-undang No. 23 Tahun 2004 tentang PKDRT di sebutkan bahwa suami dilarang menelantarkan dan

\footnotetext{
${ }^{21}$ Andang Sunarto, "Kekerasan dalam Rumah Tangga", Manhaj, Vol. 5, Nomor 3, SeptemberDesember 2017

22 Andang Sunarto, "Kekerasan dalam Rumah Tangga", Manbaj, Vol. 5, Nomor 3, September-Desember 2017
} 
membatasi/melarang istri bekerja yang layak supaya berada dalam kendali suami, dalam Pasal 49 diancam dengan pidana penjara maksimal 3 tahun penjara dan denda Rp. 15.000.000. Hasil penelitian, disimpulkan bahwa menurut hukum Islam, pasal 9 ayat (1) sesuai dengan konsep penelantaran dalam Islam, akan tetapi dikategorikan sebagai tindak pidana itu terlalu dini, karena dalam Islam mempunyai solusi yang lebih efektif, untuk pemidanaan ini adalah jalan akhir. Dan pelarangan suami kepada istri untuk bekerja dalam Pasal 9 ayat (2) tidak di anggap sebagai pidana kalaulah alasan suami melarangnya karena pekerjaan istri tidak layak dan haram menurut syariat, serta berakibat kepada terbengkalainya kewajiban istri terhadap suami dan anak-anaknya dalam rumah tangga. Akan tetapi bila alasan suami melarang istri ini karena suami bertujuan untuk mengendalikan hidup istri yang berakibat kepada suami mendzalimi istri, maka yang demikian itu dilarang oleh Islam. Apabila pemidaan dalam Pasal 49 ini sebagai jalan terakhir dan untuk kemaslahtan maka termasuk pidana ta'zir dalam pidana Islam. ${ }^{23}$

Uraian di atas menjelaskan jenis atau macam perbuatan yang termasuk kekerasan dalam rumah tangga. Penelantaran suami terhadap termasuk KDRT (UU. No. 23 tahun 2004 tentang KDRT). Oleh karena itu jika terjadi penelantaran suami terhadap istrinya dikenakan sanksi hukuman penjara ataupun denda. Hal ini sama dengan penjelasan yang ada di hukum Islam yaitu hukuman ta'zir bagi pelaku KDRT tersebut.

Setelah menjelaskan sanksi hukuman ta'zir yang dikenakan kepada pelaku kekerasan dalam rumah tangga menurut hukum Islam. Sebagai bahan tambahan selanjutnya dijelaskan sanksi hukuman pelaku kekerasan dalam rumah tangga dalam Undang-Undang nomor 23 tahun 2004 pasal 5 dijelaskan sebagai berikut: "Setiap orang dilarang melakukan kekerasan dalam rumah tangga terhadap orang dalam lingkup rumah tangganya. ${ }^{24}$

${ }^{23}$ Dede Sutrisna, Analisis Hukum Islam Terhadap Penelantaran Suami Kepada Istri Dalam UndangUndang No. 23 Tabun 2004 Tentang Penghapusan Kekerasan Dalam Rumah Tangga, http://repository.unisba.ac.id/handle/123456789/4515 (diakses pada 27 Januari 2021). h. $3-4$

${ }^{24}$ Undang-Undang RI Nomor 23 Tahun 2004 Tantang kekerasan Dalam Rumab Tangga, 2007, 
Berdasarkan penjelasan undang-undang di atas dapat dianalisa setiap orang dilarang keras melakukan kekerasan dalam rumah tangga, baik dalam bentuk kekerasan fisik, kekerasan psikis, kekerasan sekusal, atau kekerasan rumah tangga. Kesemuanya menjadi satu aturan hukum yang wajib dipatuhi, termasuk suami kepada istri, sehingga suami tidak dibolehkan melakukan kekerasan dalam bentuk apapun kepada istrinya, dan dalam keadaan apapun. Dengan demikian UndangUndang nomor 23 tahun 2004 tersebut bertujuan untuk menempatkan manusia sesuai dengan tempatnya yang tidak boleh disakiti oleh siapapun. Kemudian untuk melakukan penerapan hukum terhadap para pelaku adalah dengan menghukum pelaku sesuai dengan ketentuan yang berlaku walaupun masih banyak kendalanya, untuk itu diperlukan langkah yang optimal melalui pencegahan dengan menerapkan sanksi yang maksimal sehingga para pelaku akan takut untuk melakukan tindak pidana kekerasan dalam rumah tangga.

Hukum sebagai kaedah sosial tidak terlepas dari nilai-nilai sosial yang berlaku dalam suatu masyarakat, hukum yang baik adalah hukum yang sesuai dengan hukum yang hidup dalam masyarakat yang merupakan pencerminan daripada nilai yang berlaku dalam masyarakat itu. Membudayakan kesadaran hukum dan membina prilaku hukum harus dilakukan dalam penegakan hukum, baik dari segi hakikat maupun manifestasinya yang berkaitan dengan manusia. Karena itu aspek manusialah yang mengisi, mewarnai, membuat, menegakkan, melanggar, menggunakan termasuk menyalahgunakan.

Sanksi hukuman bagi setiap pelanggar kejahatan khususnya dalam tindak pidana kekerasan dalam rumah tangga harus ditegakkan, sehingga dalam UndangUndang nomor 23 tahun 2004 dijelaskan dalam pasal 44 ayat (1) dan (2) dijelaskan ketentuan pidana yang dikenakan kepada pelaku kekerasan dalam rumah tangga secara fisik yaitu: "setiap orang yang melakukan perbuatan kekerasan fisik dalam lingkup rumah tangga sebagaimana dimaksud dalam pasal 5 huruf a dipidana 
dengan pidana penjara paling lama 5 (lima) tahun atau denda paling banyak Rp. 15.000.000,00 (lima belas juta rupiah). ${ }^{25}$

Berdasarkan penjelasan di atas pihak yang melakukan kekerasan dalam rumah tangga seperti memukul istri secara fisik dikanakan hukuman pidana penjara selama lima tahun atau pembayaran denda sebanyak Rp. 15.000.000,00 (lima belas juta rupiah). Dengan demikian dliarang keras suami ataupun istri melakukan kekerasan dalam rumah tangga. Sanksi pidana yang dikenakan kepada pelaku kekerasan dalam rumah tangga menjadi hukuman bagi sipelaku.

Kekerasan dalam rumah tangga sering dibiarkan karena dianggap sebagai sesuatu yang biasa saja. Ketidakpedulian, penyalahgunaan fisik dan seksual, perkosaan terhadap anak-anak dan perempuan dewasa oleh anggota keluarga dan bukan anggota keluarga di dalam satu rumah tangga, maupun kejadian-kejadian di antara suami istri, sering berlalu tanpa dilaporkan. Oleh karena itu, kejadian seperti itu sukar ditemukan. Bahkan walaupun kejadian itu dilaporkan, sering gagal untuk melindungi korban dan gagal untuk menghukum para pelaku kekerasan tersebut.

Kajian di atas menjadi salah satu poin terpenting dalam Undang-Undang nomor 23 tahun 2004 Pasal 3, penghapusan kekerasan rumah tangga dilaksanakan berdasarkan asas penghormatan hak asasi manusia, keadilan dan kesetaraan gender, nondiskriminasi dan perlindungan korban. Kemudian dalam Pasal 4 UndangUndang nomor 23 tahun 2004 dijelaskan tentang tujuan penghapusan kekerasan dalam rumah tangga antara lain melindungi korban kekerasan dalam rumah tangga. Keberadaan Undang-undang nomor 23 tahun 2004 tersebut mengandung asas-asas yang menjunjung tinggi harkat martabat manusia di mata hukum. Hukum menjadi satu hal terpenting dalam kehidupan masyarakat karena pada dasarnya memang manusia hidup tidak bisa lepas dari hukum yang berlaku dalam komunitas masyarakat.

Dengan demikian dapat disimpulkan bahwa antara hukum Pidana Islam dan Undang-Undang nomor 23 tahun 2004 tentang penghapusan kekerasan dalam

${ }_{25}$ Undang-Undang RI Nomor 23 Tahun 2004 Tantang kekerasan Dalam Rumab Tangga, h. 190. 
rumah tangga terdapat sisi persamaan. Penerapan hukuman ta'zir atau ta'dib terhadap pelaku tindak pidana kekerasan dalam rumah tangga. Secara normatif dan subtantif ta'zir ataupun ta'dib tersebut bersumber dari keputusan pemerintah. Hal ini tentu sama dengan negara Indonesia yang ta'zir tersebut dapat dilihat dari adanya Undang-undang KDRT tersebut yang nota bene juga bersumber dari pemerintah. Dengan demikian, pemberlakuan ta'zir ini disesuaikan dengan regulasi ataupun keputusan pemerintah yang tertuang dalam undang-undang.

\section{Simpulan}

Penjelasan di atas memberikan pemahaman bahwa sanksi pidana kekerasan dalam rumah tangga adalah hukuman ta'zir yang ditetapkan penguasa (pemerintah), karena tidak dijelaskan dalam al-Qur'an ataupun Hadist, sehingga keberadaanya diserahkan kepada keputusan penguasa. Hukuman (jarimah) ta'zir ini berbeda dengan hukuman lainnya seperti pembunuhan, perzinahan, pencurian dan lainnya yang penjelasannya terdapat dalam hukum Islam. Sanksi hukuman bagi pelaku tindak pidana kekerasan dalam rumah tangga terdapat dalam Undangundang nomor 23 tahun 2004 tentang penghapusan kekerasan dalam rumah tangga. Dengan demikian, hukuman ta'zir dituangkan dalam undang-undang yang harus ditaaati oleh warga muslim Indonesia. Pemberlakuan hukuman ta'zir ini diharapan efek jera kepada pelaku sehingga tidak mengulangi kembali perbuatannya tersebut. Tujuan penerapan hukuman di tengah-tengah masyarakat antara lain untuk tidak terjadinya kasus KDRT yang bertambah atau untuk meminimalisir.

$* * * * * * * * *$ 


\section{Daftar Pustaka}

Departemen Agama RI, al-Qur'an dan Terjemahnya, Semarang: Toha Putra, 1999

Fathul Djanah DKK, Kekerasan Teradap Istri, Yogyakarta: Penerbit LKIS, 2003

Fauzi, Rahmat, Tinjauan hukum Pidana Islam Terhadap kekerasan seksual dalam rumah tangga menurut UU No. 23 tabun 2004 tentang penghapusan kekerasan dalam rumah tangga, http://digilib.uinsgd.ac.id/2295/, (diakses pada 27 Januari 2021).

Ichwanto, Alfan Maulidin, "Tindak Pidana Penganiayaan dalam Hukum Pidana Islam”, Al-Qanun, Vol. 20, No.1, Juni 2017

Kristianto, Agustinus Edy, Panduan Bantuan Hukum di Indonesia, Jakarta: Yayasan Obor Indonesia, 2008

Murpiaty, Perlindungan Terhadap Korban Akibat Kekerasan Terhadap Perempuan Dalam Rumah Tangga. Makalah

Nazir, Muhammad, Metode Penelitian, Jakarta: Ghalia Indonesia, 2005

Rofiah, Nur, "Kekerasan Dalam Rumah Tangga dalam Perspektif Islam”, Wawasan: Jurnal Ilmiah Agama dan Sosial Budaya, 2, 1, Juni 2017

Soeroso, Moerti Hadiati, Kekerasan Dalam Rumah Tangga, Jakarta: Sinar Grafika, 2010

Sukardi, Didi, "Kajian Kekerasan Rumah tangga Dalam Perspektif Hukum Islam Dan Hukum Positif”, Mabkamah, Vol. 9 No. 1 Januari 2015

Sunarto, Andang, "Kekerasan dalam Rumah Tangga", Manhaj, Vol. 5, Nomor 3, September-Desember 2017

Sutrisna, Dede, Analisis Hukum Islam Terbadap Penelantaran Suami Kepada Istri Dalam Undang-Undang No. 23 Tahun 2004 Tentang Penghapusan Kekerasan Dalam Rumah Tangga, http://repository.unisba.ac.id/handle/123456789/4515 (diakses pada 27 Januari 2021).

Sutrisna. Dede, Analisis Hukum Islam Terhadap Penelantaran Suami Kepada Istri Dalam Undang-Undang No. 23 Tahun 2004 Tentang Penghapusan Kekerasan Dalam Rumah Tangga, http://repository.unisba.ac.id/handle/123456789/4515.

Undang-undang Nomor 1 Tahun 1974 Tentang Perkawinan

Undang-undang Nomor 1 Tahun 1974 Tentang Perkawinan dan Peraturan Pemerintah nomor 9, 1975

Undang-Undang RI Nomor 23 Tahun 2004 Tentang kekerasan Dalam Rumah Tangga, 